darem Zmartwychwstałego, który posyła go, by mógł powstać Kościół Zgromadzenie zdolne do sprawowania liturgii.

Podsumowując obrady w Radomiu, ks. prof. dr hab. Adam Durak w serdecznych słowach podziękował wszystkim prelegentom i uczestnikom za czynny i liczny udział w sympozjum. Szczególne wyrazy wdzięczności skierował na ręce ks. prof. dra hab. Jerzego Kopcia, który przez ostatnie lata przewodniczył Sekcji Wykładowców Liturgiki. Nie zabrakło też podziękowania władzom Radomskiego Seminarium Duchownego, które przez dwa dni gościnnie przyjmowało liturgistów z całej Polski.

Kraków

KS. PRZEMYSEAW NOWAKOWSKI CM

Ks. Jerzy Chmiel

\title{
PIERWSZE PRZEKŁADY NOWEGO TESTAMENTU W DZIEJACH i KULTURZE EUROPY ŚRODKOWEJ i PÓŁNOCNEJ KONFERENCJA NAUKOWA W ZIELONEJ GÓRZE (1998)
}

Instytut Historii Wyższej Szkoły Pedagogicznej w Zielonej Górze i Towarzystwo Studiów Łużyckich tamże zorganizowały w dniach 25-26 września 1998 r. konferencję naukową nt. „Pierwsze przekłady Nowego Testamentu w dziejach i kulturze Europy Srodkowej i Północnej”. Okazją była 450. rocznica powstania jednego $\mathrm{z}$ najcenniejszych zabytków piśmiennictwa łużyckiego, a mianowicie przekładu Nowego Testamentu na język dolnołużycki (żarski) przez Mikołaja Jakubicę, który żył w pierwszej połowie XVI wieku (1500?-1563?).

Łużyczanie to ostatni już naród, jaki po tysiącu lat od czasów podbojów tej ziemi przez Niemców ocalał spośród wielu ludów słowiańskiego Połabia, czyli obszarów położonych na zachód od Odry i Nysy Łużyckiej, sięgających poza Łabę aż po Soławę (niem. Saale). Łużyce Zachodnie to teren w granicach Niemiec od Brandenburgii po Chociebuż (niem. Cottbus) i Budziszyn (niem. Bautzen). Oblicza się, że żyje tam ok. 60 tys. Lużyczan. Natomiast Łużyce Wschodnie, leżące między Nysą Łużycką od zachodu a Bobrem i Kwisą od wschodu, znalazły się po 1945 roku w granicach Polski. W Buczynach mieści się Ośrodek Kultury Łużyckiej, który zajmuje się problematyką sorabistyczną (czyli Serbów Łużyckich).

Mikołaj (Miklawš) Jakubica był mnichem augustiańskim klasztoru w Żaganiu, najprawdopodobniej skrybą bibliotecznym, a klasztor żagański słynął ze swej biblioteki (ponad 1 tys. woluminów, obecnie we Wrocławiu). w czasie reformacji Jakubica stał się zwolennikiem Lutra i został pierw- 
szym pastorem luterańskiej gminy w Lubanicach, gdzie poprzednio był rzymskokatolickim proboszczem. Jakubica pracował nad swoim przekładem Nowego Testamentu siedem lat, ukończył rękopis dnia 1 sierpnia 1548 r. Rękopis nie został dotąd wydrukowany. Jakubica chciał stworzyć ogólny język łużycki (łużycka koinē). Pomagał sobie językiem czeskim, znał też i polski, stąd wpływy katolickie.

Jak pisze prof. Tadeusz Lewaszkiewicz, językoznawca poznański, reformacja $w$ wielu krajach przyczyniła się do rozwoju lub wręcz powstania drukowanego piśmiennictwa, ponieważ Luter et consortes glosili potrzebę szerzenia zasad wiary w językach narodowych. Za życia Lutra nie ukazała się jednak żadna książka łużycka, gdyż nie darzył on sympatią Łużyczan, dążąc zapewne do szybkiego zgermanizowania ludności słowiańskiej na obszarach podbitych przez Niemców. W tej sytuacji przekład Jakubicy stał się symbolem woli życia narodu, który ma swój język. Łużycki językoznawca z Budziszyna, prof. Heinz Schuster-Šewc stwierdza, ze przekład Jakubicy jest pionierskim dziełem serbskiej filologii i ważnym pomnikiem językowym. W późniejszych latach ukazały się katolickie przekłady Nowego Testamentu na język łużycki, dokonane przez katolickiego proboszcza Jurija Augustina Switlika (1688 i 1710).

\section{Bibliografia:}

T. Lew aszkiewicz, Eużyckie przeklady Biblii, Warszawa 1955 (rec. w RBL 49, 1996, ss. 136n, pióra R. Leszczyńskiego).

W. Pi w on sk i, Lubanicki zabytek języka dolnotużyckiego, „Lusetia Orientalis", Żary 1998.

Konferencja w Zielonej Górze '98 zgromadziła znawców sorabistyki z różnych - bez przesady - stron świata (Polska, Niemcy, Kanada). Piszący te słowa był chyba jedynym, który po raz pierwszy zapoznał się z problemami łużyckimi.

Merytorycznie konferencję podzielono na trzy sekcje: 1 . W kręgu Jakubicy i Łużyc, 2. Nowy Testament w dziejach i kulturze Europy, 3. Biblistyczna translatoryka.

Wspomniany już prof. Heinz Schuster-Šewc przedstawił w wybornej polszczyźnie - jak przystało na absolwenta UJ i doktora honoris causa UJ w 1998 roku - przekład Jakubicy w kontekście wysiłków Dolnolużyczan stworzenia własnego języka kościelnego. O filologicznych aspektach przekładu Jakubicy mówili: prof. G. Schaarschmidt (Victoria, Kanada), prof. K. Gutschmidt (Drezno), dr D. Teichmann (Berlin), prof. E. Siatkowska (Warszawa), C. Pjech (Berlin) i inni. Interesujące szczegóły z historii recepcji Biblii (Wirkungsgeschichte) w kulturze lużyckiej, a nawet bizantyjskiej, podali dr. B. Burda (Zielona Góra), mgr I. Sochacka (tamże) i dr J. Dudek (tamże). Ciekawą panoramę stworzyła historia translatoryki biblijnej: prof. I. Kwilecka (Poznań) przedstawiła najciekawszy (jej zdaniem) przekład, jakim jest Biblia brzeska; prof. B. Piotrowski (Poznań) mówił 
o przekładach Biblii w rejonie Bałtyku (Balticum mare protestanticum!); prof. R. Leszczyński (Łódź) o ewangelickich przekładach NT w XVI-wiecznej Polsce. Nie brakło wystąpień na temat przekładu S. Murzynowskiego i jego ortografii polskiej (prof. J. Małkek z Torunia i dr A. Luczek z Poznania). Prof. S. Borawski (Zielona Góra) przedstawil swoje badania nad przekładami Ps 51/50/Miserere. Niżej podpisany mówił o semiotyce przekładu Biblii Leopolity.

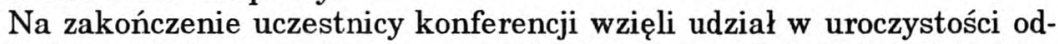
słonięcia i poświęcenia obelisku w kształcie otwartej księgi Biblii (jedyny tego rodzaju znany mi pomnik!) dla upamiętnienia wielkiego syna Wschodnich Łużyc, Mikołaja Jakubicy, który to obelisk stanął przed kościołem w Lubanicach, zaliczanym do najstarszych i najpiękniejszych kościołów na Dolnych Łużycach, gdzie znajduje się też późnogotycka rzeźba Chrystusa Ukrzyżowanego, dłuta samego Jakubicy, tłumacza i rzeźbiarza. Było piękne ekumeniczne nabożeństwo Słowa Bożego, wzniosłe przemowy po polsku, łużycku (nie powiem, czy dolno-, czy górno-) i niemiecku. Śpiewał urzekająco chór łużycki (dzieci) z Niemiec i polska schola z Lubanic. Było dużo gości z Łużyc po obu stronach granicy. Pogoda sprzyjała, mile spotkanie przy stole z poczęstunkiem, a nade wszystko atmosfera przyjaźni, pokoju i refleksji historycznej. Ktoś powiedzial, że to jest pomost do zjednoczonej Europy. Chyba tak.

Materiały z konferencji zostaną opublikowane.

Kraków

Ks. JERZY CHMIEL

\section{Ks. Jerzy Chmiel}

\section{BIBLIA SLAVICA}

Inicjatywa wydania drukiem najstarszych przekładów słowiańskich Pisma świętego powstała przed dziesięciu laty. Ale już w roku 1965 ks. Władysław Smereka wysunął pierwsze propozycje. Powstała grupa inicjatorska, w skład której wchodzili: prof. Stanisław Urbańczyk, prof. Karol Estreicher, dr Wanda Górecka i Czesław Miłosz. Prof. Urbańczyk zainteresował prof. Olescha, a ks. Smereka zwracał się listownie do Czesława Miłosza w sprawie wydania Biblii Leopolity ${ }^{1}$. Zaczęto zbierać fundusze, nie wszyscy byli chętni, ale

${ }^{1}$ Zob. J. C h mi e l, Biblijne pomniki polskiej mowy. Inicjatywy edytorskie Ks. Prof. Wtadystawa Smereki, RBL 34/1981/341-343. 